\title{
Fruit Juice
}

National Cancer Institute

\section{Source}

National Cancer Institute. Fruit Juice. NCI Thesaurus. Code C71952.

The liquid produced by squeezing or crushing fruit. 